\title{
Tillichova teorija religijskih simbola
}

\author{
Dubravko ARBANAS* \\ UDK: 1 Tillich, $\mathrm{P}^{*} 2-135$ - Izvorni znanstveni rad \\ Primljeno: 29. travnja 2017. • Prihvaćeno: 4. rujna 2017.
}

Sažetak: Premda je po vlastitom priznanju svoj cjelokupni teološki rad usmjerio prema interpretaciji religijskih simbola kako bi postali razumljivi svim ljudima, Paul Tillich sa svojom teorijom simbola odnosno religijskog jezika izazvao je brojne polemike, stoga ćemo nastojati prikazati njene bitne odrednice. Uže područje istraživanja nekoliko je njegovih ključnih eseja, a pored toga metoda proučavanja odnosi se i na analizu relevantnih ideja njegovih glavnih kritičara. Kritičkom analizom autor je došao do zaključka da je Tillich prije svega želio prevladati pogubne posljedice 'doslovnog' i 'nadnaravnog' tumačenja vjerskih učenja, zbog čega je zagovarao filozofiju religije koja bi pomogla osnaživanju značenja simbola i rasvjetljavanju simboličke prirode glavnih vjerskih učenja. Pritom je posebno naglašavao da se simboli nipošto ne smiju poistovjećivati s onim što simboliziraju, kako ne bi došlo do njihova demoniziranja, odnosno do tog da se apsolutiziraju te tako postanu sami sebi surhom i predmetom idolopokloničkog obožavanja; nego da kao 'sredstvo' ukazivanja na Sveto moraju sadržavati i svoju vlastitu negaciju, a što je zapravo afirmacija one stvar-

* Dr. sc. Dubravko nosti koja nam u svojoj biti ostaje do kraja nespoznatljiva. $U$ Arbanas, Trg Slobode 5, 31000 Osijek, Hrvatska, adubravko@gmail.com tom smislu simbol raspetog Krista na križu najviše odgovara sadržaju i značenju vjere, a kao konačni kriterij svih religijskih simbola predstavlja glavnog čuvara protiv njihova demoniziranja.

Ključne riječi: znak, simbol, participacija, religijski jezik, vjera, bezuvjetno, vrhunsko, sveto, Bog, Krist, istina.

\section{Uvod}

Tillich je već na početku svoje karijere uočio da su mnogi tradicionalno ključni simboli kršćanstva sve više gubili 
svoju 'snagu' tako što su za većinu ljudi imali sve manje 'smisla. ${ }^{1}$ Razlog za to vidio je jednim dijelom u velikim društvenim promjenama u Europi s početkom dvadesetog stoljeća, ali je za to krivio i teologe koji su svojim 'doslovnim' (literally) i 'nadnaravnim' (supranaturalistically) interpretacijama vjerskih učenja pogodovali izoliranju teološke refleksije od interesa suvremenog društva. Kako bi popravio tu situaciju, zagovarao je filozofiju religije koja bi pomogla osnaživanju značenja simbola i rasvjetljavanju simboličke prirode glavnih vjerskih učenja. Teologija je preuzela mnoštvo pojmova iz područja filozofije, znanosti i običnog govornog jezika, pa često upada u koliziju s pretpostavljenim značenjem tih pojmova koje oni imaju u diskursima kojima izvorno pripadaju. Stoga je autor nastojao zaštititi 'racionalnost teologije', uvodeći nekoliko načela, ${ }^{2}$ a u ovom kontekstu korisno je prisjetiti se načela 'semantičke racionalnosti', koje je bilo posebno prisutno u razdoblju skolastike, kao svojevrsna 'kuća čišćenja' (clearing house) filozofije i teologije od neprikladnih značenja pojedinih pojmova, oko čega su se u novije vrijeme posebno trudili i logički pozitivisti. ${ }^{3}$ Unatoč tome, mnogi su pojmovi do danas ostali nejasni i proturječni, što osobito vrijedi za značenje 'simbola' kao jednog od najvažnijih religijskih pojmova, ${ }^{4}$ jer čin vjere sadrži u sebi posebnu vrstu spoznaje koja je kvalitativno ra-

${ }^{1}$ Tillich općenito razlikuje dvije osnovne 'teorije simbola': a) 'negativne teorije' - koje u kontekstu svojih psiholoških i socioloških analiza smatraju da simboli tek 'nesvjesno' odražavaju određene aspekte subjektivne i društvene stvarnosti iz kojih su i nastali (Marx, Nietzsche i Freud), što je posebno opasno za religijske simbole jer ih se u tom smislu svodi na golu subjektivnost i poriče bilo kakva mogućnost ukazivanja na objektivnu stvarnost izvan njih; b) 'pozitivne teorije' - koje svojim kulturološkim i morfološkim analizama simbola također naglašavaju važnost subjektivnog elementa, koji kao 'duša kulture' ukazuje na objektivnu stvarnost pri čemu ključnu ulogu ima 'stil' (style) u kojem svi oblici kulturnog života postaju simboli, dok kritičko-idealistička analiza poistovjećuje simbolički i objektivni karakter kulturnog stvaralaštva te time uvelike proširuje ulogu i značenje simbola (Cassirer). Suprotno navedenim teorijama, Tillich opisuje svoju teoriju 'religijskih simbola' kao 'nadnaravni realizam' (transcendent realism), ali ona proizlazi iz njegovog ranog djela Filozofija religije (Religionsphilosophie).

${ }^{2}$ Vidi G. F. THOMAS, The Method and Structure of Tillich's Theology, u: C. W. KEGLEY, R. W. BRETALL (ur.), The Theology of Paul Tillich, New York, 1964., 94.

${ }^{3}$ S obzirom na ove posljednje TIllich naglašava: »Jedina kritika u tome je da ova kuća čišćenja predstavlja vrlo malu sobu, možda samo kutak kuće, a ne stvarnu kuću. Ona isključuje najveći dio života. Ali bi mogla postati korisna ako se poveća u dosegu i prihvaćanju stvarnosti koja nadilazi tek logičku kalkulaciju. (... ) naime, postoje nivoi stvarnosti koji se uvelike razlikuju, stoga zahtijevaju različite pristupe i različite jezike, jer ne može sve u stvarnosti biti zahvaćeno jezikom koji je najprikladniji za matematičke znanosti. Uvid u ovu situaciju najpozitivnija je strana činjenice da je problem simbola ponovno ozbiljno uzet u obzir.«P. TILLICH, The Nature of Religious Language, u: R. C. KIMBALL (ur.), Theology of Culture, New York, 1964., 53.-54.

${ }^{4}$ Carl G. Jung svojom je interpretacijom mitoloških i religijskih simbola utjecao na Tillichovu teoriju simbola smatrajući kako je: $\gg($... $)$ povijest protestantizma stalan 'ikonoklazam' ('razaranje slika', dakle religijskih simbola), dosljedno odvajanje naše svijesti od univerzalnih ljudskih 'arhetipova' koji su prisutni u svačijoj podsvijesti.« P. TILLICH, Author's Introduction, u: Protestant Era, Chicago, 1957., xix. 
zličita od spoznaje u znanstvenom radu filozofa, teologa i drugih istraživača. Tillich je smatrao da vjera ima naglašeno egzistencijalno, subjektivno i posvećujuće obilježje koje je prisutno i u intelektualno najprimitivnijim religijama, a u kontekstu filozofskog razmatranja bîti religije nastojao je pokazati različita značenja i konotacije izraza 'Bezuvjetno', koji je koristio kako bi označio nutarnju beskonačnost ljudske egzistencije i svekolikih 'značenja.' A kako se samo simboličkim jezikom može izraziti ono vrhunsko, posve je razumljivo da se i čovjekova vrhunska briga mora izražavati simbolički i to u skladu s autorovom teorijom religijskog jezika i mita, jer ne postoji neposredniji ili 'doslovniji' (literal), odnosno jednoznačan način izražavanja čovjekova susreta s Bogom:

$\gg$ Religijski simboli ne trebaju opravdanje ako je shvaćeno njihovo značenje. Zato što je njihovo značenje $u$ tome što su oni jezik religije $i$ jedini način kojim ona može izraziti sebe izravno. Neizravno i misaono religija se može izraziti i teološkim, filozofskim te umjetničkim izrazima. Ali njen izravan izraz same sebe je simbol i jedinstvena skupina simbola koju nazivamo mit. $\ll^{6}$

\section{Karakteristike i funkcije religijskih simbola}

Budući da se izvorno značenje simbola (symbols) često brka s različitim znakovima (signs), indikacijama ili metaforama, Tillich razlikuje 'reprezentativne simbole' (representative symbols), koji nešto predstavljaju i koji se uglavnom koriste $\mathrm{u}$ jeziku povijesti, umjetnosti i religije, te 'nesuvisle simbole' (discursive symbols), koji su zapravo samo znakovi kakve nalazimo, na primjer, u matematici ili logici. ${ }^{7}$ Međutim, simboli i znakovi u bîti su slični jer 'ukazuju' na nešto što je 'izvan njih' i kao takvo

\footnotetext{
${ }^{5}$ Dakle, Bezuvjetno nije metafizički entitet, odnosno nekakvo najviše ili nadnaravno biće pa, stoga, ne možemo reći da 'egzistira', nego taj izraz označava 'uvjet' i simbol: a) 'temelja, dubine i ponora' svekolike egzistencije i svih značenja, koji ne možemo izjednačiti sa sveukupnim postojanjem i značenjima, pa stoga ne može biti potpuno obuhvaćen ni jednim pojmom; b) nutarnjeg zahtjeva u svakom našem smislenom mišljenju, govoru i akciji; c) u kojem se susreću subjekt i objekt tako što se njegovo značenje paradoksalno ispunjava, suočavajući se uvijek s višim zahtjevima; d) i konačno, to je simbol naše vrhunske brige koja nas se bezuvjetno tiče.

${ }^{6}$ P. TILLICH, The Meaning and Justification of Religious Symbols, u: P. TILLICH: Writings in the Philosophy of Religion, Main Works = Hauptwerke, 4, John P. Clayton (ur.), Berlin - New York, 1987., 415. O važnosti takvog istraživanja svjedoči i sam autor: »( ... ) moj cjelokupni teološki rad bio je usmjeren točno prema interpretaciji religijskih simbola na takav način da ih svjetovan čovjek - a mi smo svi svjetovni - može razumjeti i biti njima pokrenut.«P. TILLICH, The Restoration of Religious Symbols, u: B. D. MACKENZIE (ur.), Ultimate Concern: Tillich in Dialogue, New York London, 1970., 88.-89.

${ }^{7}$ Tillich je ovu podjelu preuzeo od Johna H. Randalla koji mu je kao povjesničar filozofije na Sveučilištu Columbia (Columbia University) bio višegodišnji suradnik u nastavi.
} 
'različito od njih', a autorov omiljeni primjer za to znak je crvenog svjetla na semaforu koji nema nikakve suštinske povezanosti sa zaustavljanjem auta, ali na temelju konsenzusa ipak ukazuje na potrebu zaustavljanja pred tim znakom sve dok traje takav društveni dogovor. ${ }^{8} \mathrm{Na}$ isti način i simboli 'ukazuju izvan sebe' (points beyond themselves), što predstavlja njihovu prvu karakteristiku i temeljnu funkciju jer ukazuju na stvarnost zbog koje su i uspostavljeni. Međutim, za razliku od znakova koji ne participiraju u stvarnosti onoga na što ukazuju, simboli 'sudjeluju u toj stvarnosti' (participate in the reality), što predstavlja drugu karakteristiku svakog simbola. Oni koriste 'simboličku građu' koju nalaze u svakodnevnom značenju riječi, povijesnim prikazima, ljudskim osobinama i vrlinama u opisima božanstava itd., ali pritom ukazuju na nešto što se ne može neposredno ili doslovno izraziti, nego poput svojevrsne 'parabole' (što je također simbolički izraz) mora biti izraženo posredno kroz simboličku građu. To 'nešto' može biti konotacija ili uključeno pojmovno značenje riječi koje nadilazi čovjekovo iskustvo, odnosno posebna dimenzija stvarnosti koja nije otvorena prilikom uobičajenog susreta sa stvarnošću kao što je to slučaj u umjetničkim oblicima izražavanja, ali to može biti i 'vrhunska stvarnost' (ultimate reality) izražena simbolima čija je građa uzeta iz konačne stvarnosti:

$\gg$ Pojam predstavljanja [representation] podrazumijeva ovaj odnos. Predstavnik osobe ili ustanove participira u časti onih koji su ga tražili da ih predstavlja, ali nije 'on' taj kojeg se časti, nego je to onaj ili ona koju on predstavlja. U tom smislu možemo općenito reći da simbol sudjeluje u stvarnosti koju simbolizira. Tako zrači snagu bitka i značenje [power of being and meaning] onoga za što je postavljen. $^{9}$

Na temelju reprezentativne funkcije simbola dolazimo do njihove treće karakteristike, odnosno druge i najvažnije funkcije kojom nam 'otvaraju dimenzije stvarnosti' (opening up dimensions of reality) koje bi nam inače ostale skrivene i nedostupne, što se najlakše može objasniti na primjeru umjetnosti koja nam kroz svoje književne, pjesničke, likovne i glazbene oblike otvara posebno 'područje ljudskog duha' kojem se inače ne bi moglo pristupiti ni na jedan drugi način, a najmanje onaj pojmovno-logički ili znanstveni. Svi umjetnički simboli otvaraju nas za 'estetičko isku-

\footnotetext{
${ }^{8}$ Takav konsenzus vrijedi za slova, brojeve i mnoge druge znakove, a djelomično čak i za riječi, jer i one ukazuju na stvarnost izvan sebe, odnosno na određene zvukove koji su dobili svoje značenje svojevrsnim dogovorom pripadnika određenog govornog područja. Problem je u tome što se takvi znakovi često nazivaju simbolima zanemarujući njihovu temeljnu razliku, što dovodi do otežanog razumijevanja izvornog značenja simbola, jer slova abecede: $\gg($... ne participiraju u zvuku na koji ukazuju; dok s druge strane, zastava sudjeluje u snazi kralja ili nacije za koju je postavljena i koju simbolizira.«P. TILLICH, The Nature of Religious Language, 55.

${ }^{9}$ P. TILLICH, The Meaning and Justification of Religious Symbols, 415.-416.
} 
stvo' lijepog, a na isti način religijski simboli pobuđuju u nama unutarnje iskustvo moralnog dobra, što nas sve zajedno oplemenjuje i izgrađuje u duhovnom, a ne samo u spoznajnom smislu. Posredstvom religijskih simbola dolazimo do vrhunske stvarnosti, tako što pomoću 'simbola Svetog' (symbols of the Holy), odnosno određenih mjesta, predmeta, knjiga, slika, osoba ili događaja, otkrivamo i nešto od 'Svetog po sebi' (Holy-itself), pri čemu i sami 'doživljavamo' svetost koja se nalazi u temelju svekolike stvarnosti i koju ne mogu izraziti nikakvi filozofsko-teološki ili znanstveni pojmovi. U tom smislu simboli nam pokazuju još jednu važnu karakteristiku, odnosno funkciju koja se odnosi na 'otvaranje dijelova naše duše' i njihovu povezanost $s$ dotičnim nivoima stvarnosti. ${ }^{10}$ Takvo iskustvo potvrđuje jedinstvenu ulogu svakog pojedinog simbola, odnosno da se nijedan ne može svjesno i proizvoljno stvarati ili zamijeniti bilo kojim drugim kao što je to slučaj kod znaka, što predstavlja njihovu petu karakteristiku. ${ }^{11}$ Ovdje je zapravo riječ o svojevrsnom 'izrastanju' simbola iz individualne ili kolektivne podsvijesti, a ne o konvenciji i svrsishodnosti kakvu nalazimo kod znakova, stoga bismo mogli metaforički reći da su se simboli 'rađali i umirali' u skladu s promjenjivim povijesnim okolnostima, što predstavlja njihovu šestu karakteristiku. Pritom je važno naglasiti da nijedan reprezentativni simbol ne može vršiti svoje funkcije i kao takav trajati ako ga nije prihvatila određena društvena, religijska ili kulturna zajednica; u protivnom dolazi do procesa odumiranja simbola kao što je to bio slučaj s antičkim bogovima, koji su potpuno izgubili svoje religijsko značenje te postali metafore poetsko-simboličkog izražavanja. ${ }^{12}$ Posljednja karakteristika simbola njihova je integracijska i dezintegracijska snaga koja se jednako odnosi na pojedince kao i na šire zajednice, o čemu također svjedoče brojni primjeri iz povijesti, kada su, na primjer, pojedini religijski simboli imali čak 'zacjeljujuću' snagu ('healing' power). S druge strane, svjedoci smo kako su politički simboli poput nacističkih kod njihovih pristaša izazivali

${ }^{10}$ Ovu 'dvosjeklost' (double-edged) simbola najbolje ćemo shvatiti na njihovom religijskom primjeru jer su oni: »( ... ) usmjereni prema beskonačnom koje simboliziraju 'i’ prema konačnom kroz koje to simboliziraju. Oni guraju beskonačno dolje do konačnog, a konačno gore do beskonačnosti. Oni otvaraju božansko za ljudsko i ljudsko za božansko. Na primjer, ako Boga simbolizira 'Otac', on je spušten dolje do ljudskog odnosa oca i djeteta. Ali je taj ljudski odnos istovremeno uzet u obzir u obrascu božansko-ljudskog odnosa. Ako je 'Otac' korišten kao simbol za Boga, očinstvo je viđeno u njegovoj teonomnoj i sakramentalnoj dubini.«P. TILLICH, God as Being and the Knowledge of God, u: Systematic Theology, I, Chicago, 1951., 240.-241.

${ }^{11} \gg$ Ne može se proizvoljno 'napraviti' religijski simbol od isječka svjetovne stvarnosti. To ne može čak ni kolektivna podsvijest kao velik izvor za stvaranje simbola. Ako je isječak stvarnosti korišten za simbol Boga, onda je područje stvarnosti iz koje je uzet, takoreći, uzdignuto u područje svetog. Ono više nije svjetovno. Ono je teonomno.« Isto, 241.

${ }^{12}$ Vidi P. TILLICH, Which Religious Symbols Are Now Dead?, u: B. D. MACKENZIE (ur.), Ultimate Concern: Tillich in Dialogue, New York - London, 1970., 147.-149. 
euforične osjećaje uzvišenosti i agresivni fanatizam, a kod neistomišljenika veliki nemir, tjeskobu i strah, što sve pokazuje kako su simboli vrlo daleko od bilo kakvog 'bezopasnog semantičkog izražavanja'. Ove opće karakteristike simbola odnose se i na religijske simbole koji se:

$\gg($... ) razlikuju od drugih po činjenici što su oni prikaz [representation] onoga što je bezuvjetno izvan pojmovnog područja, oni ukazuju na vrhunsku stvarnost koja se podrazumijeva u svakom religijskom činu, na 'bezuvjetno nadnaravno' [the unconditioned transcendent]. (...) Religijski simboli nemaju temelja u iskustvenom, ali ni u kulturološkom području značenja. Zapravo oni nemaju uopće nikakvog temelja. Govoreći jezikom religije, oni su predmet vjere. Nemaju nikakve druge zahtjeve osim da predstavljaju [represent] nematerijalno nadnaravno koje, štoviše, nema potrebe za njima kako bi počelo postojati. ${ }^{13}$

\section{Dva nivoa religijskih simbola}

\subsection{NADNARAVNI NIVO}

Tillich je razlikovao dva nivoa odnosno tipa religijskih simbola, naime temeljni ili 'podupirući' koji naziva 'nadnaravni nivo' (transcendent level), na kojem je utemeljena religijska nepristranost $\mathrm{i}$ koji dopire do područja izvan iskustvene stvarnosti, a drugi je njime 'podržan' pa ga naziva 'naravni nivo' (immanent level) koji, kako smo već napomenuli, ukazuje na nešto izvan sebe i 'otvara nivoe stvarnosti' (opening up levels of reality), što u ovom kontekstu predstavlja nadnaravno područje zbog kojeg su simboli i uspostavljeni. One koji pripadaju prvom nivou naziva 'stvarnim' ili 'ukazujućim simbolima' (pointing symbols), a one koji se odnose na drugi nivo naziva 'samonadilazećim simbolima' (self-transcending symobols). ${ }^{14}$ Ako vjeru shvaćamo kao vrhunsku brigu, onda bi u tom smislu i temeljni simbol te brige kao i

\footnotetext{
${ }^{13}$ P. TILLICH, The Religious Symbol / Symbol and Knowledge (1940-1941), u: P. TILLICH: Writings in the Philosophy of Religion, Main Works = Hauptwerke, 4, John P. Clayton (ur.), Berlin - New York, 1987., 254.-255. Zaključimo naš prikaz ovih sedam karakteristika simbola autorovim osvrtom na neke od njih u kontekstu njegove kristologije: $\gg($... simbol je utemeljen na stvarima i događajima i participira u snazi onoga što simbolizira. Stoga se simboli ne mogu po volji zamjenjivati, nego moraju biti interpretirani dokle god su živi. Oni mogu umrijeti (... ) Teolog ne može dati svoj sud s obzirom na život ili smrt simbola koje tumači. Ta prosudba događa se u svijesti živuće crkve i ima duboke korijene u kolektivnoj podsvijesti. (...) Novi Bitak nije ovisan o posebnim simbolima u kojima je izražen. On ima snagu da bude slobodan od svakog oblika u kojem se pojavljuje.«P. TILLICH, Symbols Corroborating the Symbol 'Resurrection of the Christ', u: Systematic Theology, II, Chicago, 1957., 164.-165.

${ }^{14}$ Vidi P. TILLICH, The Religious Symbol / Symbol and Knowledge (1940-1941), 263.-267.
} 
nadnaravnog nivoa simbola trebao biti vrhunski, odnosno Bog ${ }^{15}$ ili 'Vrhovno Biće' (Supreme Being), koje na slikovit način predstavlja 'bezuvjetno nadnaravno' (the unconditioned transcendent), a kako ta 'kvaliteta' nadilazi svaki mogući pojam bića, pa čak i predodžbu o Vrhovnom Biću, tako i 'cjelokupno znanje o Bogu ima simboličku narav. ${ }^{16}$ Budući da je riječ 'Bog' prožeta konkretnim simbolima pomoću kojih čovječanstvo izražava svoju vrhunsku brigu ili zahvaćenost nečim bezuvjetnim, a to 'nešto' nije neka stvar, nego snaga bitka u kojoj participira svako biće, onda možemo reći da je Bog glavni simbol naše vrhunske brige ili onoga što nas se bezuvjetno

$\overline{15} \gg$ Temeljni je simbol naše vrhunske brige Bog. On je uvijek prisutan u svakom činu vjere, čak i ako taj čin uključuje poricanje Boga. Tamo gdje je vrhunska briga, Bog se može poricati samo u ime Boga. Jedan Bog može poricati drugog. Vrhunska briga ne može poricati svoju vlastitu narav vrhunskog. Zbog toga ona potvrđuje ono što znači riječ 'Bog'. (... ) U svakom slučaju, onaj tko poriče Boga kao predmet vrhunske brige zapravo ga potvrđuje, zato što potvrđuje ono vrhunsko.« P. TILLICH, Symbols of Faith, u: Dynamics of Faith, New York, 2001., 52.

${ }^{16}$ Vidi P. TILLICH, The Religious Symbol / Symbol and Knowledge (1940-1941), 263.-265. Ovaj Tillichov esej izazvao je veliku polemiku te brojne kritike i nakon njegovog petog izdanja 1961., kada je Institut za filozofiju Sveučilišta u New Yorku (New York University Institute of Philosophy) sponzorirao međunarodni simpozij o religijskom jeziku, na kojem su svi sudionici bili jednodušni da je dotični esej potrebno razjasniti. A kako ovo izdanje sadrži kratke kritike Wilbura M. Urbana i Edwina E. Aubreya koje se odnose na autorov izraz 'bezuvjetno nadnaravno', mi ćemo se u tom smislu osvrnuti samo na Tillichov odgovor koji nosi naslov Symbol and Knowledge: »Ja naime mislim, da je temelj bića [ground of being] istovremeno ponor [abyss] bilo kojeg konačnog bića; i obratno, da je ponor bića [abyss of being] koji nadilazi sva posebna bića istovremeno stvaralački temelj svih oblika postojanja. Svi su oni uvjetovani njime [bitkom], ali on sâm nije ničim uvjetovan i svi su oni obuhvaćeni njime, ali on sâm nije iscrpljen njihovom beskonačnošću.« Isto, 273. A s obzirom na autorov stav da 'cjelokupno znanje o Bogu ima simboličku narav', Urban je izrazio zabrinutost da se tu zapravo radi o očiglednom 'pansimbolizmu' (pan-symbolism) koji lako vodi u naturalističke prikaze 'Boga' kako ga čovjek zamišlja, pa ćemo i ovdje navesti Tillichov odgovor: »Ja bih i danas branio tu izjavu, ali bih priznao da bilo koje simboličko znanje pretpostavlja nekakav temelj [basis] nesimboličkog znanja [non-symbolic knowledge] i da pansimbolizam uništava sam sebe. (...) Nesimbolički element u cjelokupnom religijskom znanju jest iskustvo bezuvjetnog [the unconditioned], kao granica, temelj i ponor svega uvjetovanog. To iskustvo granično je iskustvo ljudskog razuma i zbog toga se može izraziti pomoću negativnih racionalnih izraza. Ali bezuvjetno nije Bog. Bog je potvrdni pojam koji ukazuje izvan granice negativnih racionalnih izraza pa je kao takav pozitivan simbolički izraz [positive-symbolic term]. Pokušaj loše metafizike da uspostavi pojam o Bogu pomoću pozitivnih racionalnih izraza nepobitno je odbačen s Kantom, koji ovdje slijedi prevladavajuću teološku tradiciju. Pozitivni simbolički izrazi pretpostavljaju - u tome se potpuno slažem s Urbanom - da neposredna stvarnost koja je korištena u simbolu ima nekog posla s nadnaravnom stvarnošću koja je u njemu simbolizirana. Zbog toga mogu prihvatiti klasično učenje o 'analogiji bića' ['analogia entis']( ... ) Ali prihvaćajući 'analogiju bića', ne mogu prihvatiti bilo koji pokušaj njegova korištenja na način racionalnih konstrukcija. Simbolički, potvrdni pojmovi o Bogu, njegovim kvalitetama i njegovim djelovanjima, izražavaju konkretan oblik u kojem misteriozni temelj i ponor bića [mysterious ground and abyss of being] postaje vidljiv biću kao njegova vrhunska briga [ultimate concern] u činu koji nazivamo 'objava'.« Isto, 273.-274. 
tiče. Međutim, netko bi mogao pomisliti da je Bog 'samo simbol', ali to zapravo znači da je 'Bog simbol Boga', pri čemu u pojmu 'Bog' moramo razlikovati dva elementa. Prvi je element ono 'vrhunsko' (the Ultimate) - što kao 'bezuvjetno nadnaravno' predstavlja predmet našeg neposrednog iskustva pa stoga nema simboličku narav, a to je 'Bitak po sebi' (Being-itself) odnosno 'Sveto po sebi' (Holy-itself). Da su mnogobrojne kritike Tillichove teorije simbola bile korisne potvrđuje i ovaj navod kojim također priznaje da postoji barem jedna 'nesimbolička tvrdnja' o Bogu:

$\gg$ Tvrdnja da je Bog bitak po sebi [God is being-itself] predstavlja nesimboličku konstataciju. Ona ne ukazuje na nešto izvan sebe. To znači upravo ono što je izrečeno izravno i primjereno; jer ako zaista govorimo o Bogu, prvo moramo izjaviti da on nije Bog ako nije bitak po sebi. (...) oni [teolozi] moraju izraziti izričito [explicit] ono što se u religijskom razmišljanju i izražavanju podrazumijeva [implicit], a kako bi to učinili, moraju početi s najapstraktnijom i potpuno nesimboličkom tvrdnjom koja je uopće moguća, naime, da je Bog bitak po sebi ili apsolutan. Međutim, nakon što je to rečeno, ništa drugo ne može biti rečeno o Bogu kao Bogu što ne bi bilo simboličko. ${ }^{17}$

Drugi je element ono 'konkretno' - što je uzeto iz našeg svakodnevnog iskustva i simbolički primijenjeno na Boga kao 'najviše biće' (highest being), u kojem sve kontingentno postoji na najsavršeniji način pa ga se može nazvati i 'najsavršenije biće' (most perfect being), koje kao takvo predstavlja 'vrhunski i sveopći sadržaj vjere'; stoga je posebnost religijskih simbola u tome što ukazuju na ono 'bezuvjetno,

${ }^{17}$ P. TILLICH, God as Being and the Knowledge of God, 238.-239. Zbog ključne važnosti tvrdnje da je 'Bog bitak po sebi', moramo napomenuti da se autor u drugom svesku svoje Sistematske teologije vratio na poziciju pansimbolizma koji je toliko brinuo Urbana i druge kritičare, tako što je na nju gledao kao na svojevrsnu mješavinu simboličkih i nesimboličkih elemenata i tako stvorio pomutnju brkajući ‘tvrdnju o Bogu' i 'tvrdnju o tvrdnji o Bogu': »( ...) pojavljuje se pitanje (proizašlo iz javne rasprave) postoji li smisao u kojem se mora izjaviti nesimbolička tvrdnja o Bogu. Postoji takav smisao, naime, tvrdnja da je sve što kažemo o Bogu simboličko. Takva tvrdnja tvrdnja je o Bogu koji po sebi nije simboličan. Inače bismo upali u kružni argument. S druge strane, ako izjavimo 'jednu' nesimboličku tvrdnju o Bogu, čini se da će biti ugrožen njegov ekstatičko-nadnaravni [ecstatic-transcendent] karakter. Ova dijalektička poteškoća ogledalo je ljudske situacije s obzirom na božanski temelj bića. Premda je čovjek zapravo odvojen od beskonačnog, on ne bi mogao biti toga svjestan ako u tome potencijalno ne participira. To je izraženo kroz stanje bića koje se vrhunski brine [state of being ultimately concerned], stanje koje je općeljudsko bez obzira koji je sadržaj te brige. To je smisao u kojem moramo govoriti o Bogu nesimbolički, ali u uvjetima potrage za njim. Međutim, u trenutku kada opisujemo karakter tog smisla ili kada pokušavamo formulirati to za čim tragamo, događa se kombinacija simboličkih i nesimboličkih elemenata.« P. TILLICH, Beyond Naturalism and Supranaturalism, u: Systematic Theology, II, Chicago, 1957., 9. S obzirom na mnoge kritike autor je nekoliko godina nakon ovog sveska Sistematske teologije objavio još jednu 'novu' interpretaciju (restatement) religijskih simbola koju smo već citirali, a koja je kao potvrda njegovih ranijih stavova ostala bez većeg odjeka: The Meaning and Justification of Religious Symbols, 415.-416. 
beskonačno i vrhunsko' u našem duhovnom životu, a to je po autoru upravo 'Bog kao bitak po sebi' kojeg opisuje kao 'vrhunsku' ili 'svetu' stvarnost, koja bi kao takva trebala biti i naša 'vrhunska briga':

$\gg($... ) riječ 'Bog' uključuje dvostruko značenje: ona podrazumijeva bezuvjetno nadnaravno [the unconditioned transcendent], vrhunsko [the ultimate], a i predmet obdaren kvalitetama i aktivnostima. Prvo nije slikovito ili simboličko, nego zapravo u najstrožem smislu što je rečeno da jest. Međutim, drugo je zaista simboličko, slikovito. To drugo predmet je zamišljen u religioznoj svijesti. $\ll^{18}$

Previđanje razlike između ovih dvaju elemenata u našem poimanju Boga često je vodilo krivoj interpretaciji vjere i razaranju religioznog iskustva općenito, a tome je u prilog išlo i krivo poimanje Božjih atributa, odnosno Božje 'osobnosti' i 'sličnosti' s drugim bićima. Kako se to ne bi događalo, važno je i u ovom kontekstu naglasiti da sva bića participiraju u Bogu kao svom temelju, pa stoga možemo reći da sve što znamo o kontingentnim stvarima ovog svijeta, također, analoški ili sličnoznačno znamo i o Bogu, ali je isto tako važno istaknuti da to znanje o svijetu ne možemo doslovno ili jednoznačno primijeniti i na Boga kao 'potpuno drugog' (quite other) ili 'ekstatičko nadnaravnog' (ecstatically transcendent). Ovdje je zapravo riječ o 'analoškom ili simboličkom' stjecanju barem nekakvog znanja o Bogu, pri čemu religijski simboli koriste građu iz svakodnevnog iskustva tako da ju istovremeno potvrđuju i poriču. Naime, svaki takav simbol negira samog sebe u svom 'doslovnom značenju' (literal meaning), ali se i afirmira u svom 'samonadilazećem značenju' (self-transcendent meaning), tako što participirajući u stvarnosti koju simbolizira u isto vrijeme ukazuje na vrhunsku stvarnost koju prikazuje. Religijski simbol tako postaje 'sredstvo' koje, kako je rečeno, ukazuje na ono što ga beskonačno nadilazi, stoga je njegova negacija zapravo afirmacija one stvarnosti koja nam u svojoj bîti ostaje do kraja nespoznatljiva, pa se u tom smislu autor suočava s presudnim pitanjem o utemeljenosti i opravdanosti ovakvog načina ulaženja u tajnu Bitka po sebi, odnosno Boga:

»Može li segment konačne stvarnosti postati temelj za tvrdnju o onome što je beskonačno? Odgovor je da može, zbog toga što je to beskonačno zapravo bitak po sebi i zbog toga što sve participira u bitku po sebi. Analogia entis [analogija bića u bitku] nije vlasništvo upitne naravne teologije koja pokušava steći znanje o Bogu izvlačenjem zaključaka o beskonačnom iz konačnog. Analogia entis daje nam samo naše opravdanje da uopće govorimo o Bogu. To je utemeljeno na činjenici da Bog mora biti shvaćen kao bitak po sebi. $\ll^{19}$

${ }^{18}$ P. TILLICH, The Religious Symbol / Symbol and Knowledge (1940-1941), 264.

${ }^{19}$ P. TILLICH, God as Being and the Knowledge of God, 239.-240. Premda problematika Analogia entis u tradicionalnom smislu 'pravilne proporcionalnosti' (proper proportionality) nije ključna za 
Tako smo došli do onoga na 'što' simboli ukazuju (the 'referent') odnosno do pitanja 'kako' se to može dosegnuti, jer ako se do nečega može doći samo putem simbola, nameće se pitanje može li se do toga uopće doći i postoji li nesimbolička izjava o tome na što simboli referiraju? Kako smo pokazali na početku ovog poglavlja, kada odgovor na posljednje pitanje ne bi bio potvrdan, onda ni nužnost simboličkog jezika za vjeru ne bi bila dokaziva i cijeli bi nas argument odveo u pogrešan krug (vicious circle). Stoga autor postavlja pitanje o 'predmetu' religijskog simbolizma, odnosno kako taj predmet uopće možemo spoznati bez simbolā, i to samo i jedino u smislu onoga na 'što' oni ukazuju. ${ }^{20} \mathrm{~A}$ budući da ukazuju na predmet koji beskonačno nadilazi sve stvoreno, onda i s obzirom na njegovu narav moramo isključiti svaki induktivni način razmatranja i zaključivanja koji polazi od konačne stvarnosti, jer ništa prolazno ne može biti predmet religijskih simbola. Međutim, postoje dva načina koja s obzirom na taj predmet vode do istog rezultata: a) 'fenomenološki pristup' - koji ne opisuje Sveto kao nekakav poseban predmet ili emocionalni odgovor bez temelja u cjelokupnosti svih predmeta, nego kao 'kvalitetu susreta' (quality in encounter), u kojem se kroz svojevrsno mističko iskustvo nadilazi uobičajena subjekt-objekt struktura čovjekova susreta sa stvarnošću, a što predstavlja predmet njegove vrhunske brige (matter of ultimate concern) i bezuvjetnu snagu (ultimate power) svih bića; b) 'ontološki pristup' - koji analizom čovjekova bića kao takvog i njegovih različitih susreta sa svekolikom stvarnošću, odnosno njegove konačnosti i svijesti o vlastitoj prolaznosti, dolazi do pitanja o Bitku po sebi kao priusu svega što postoji, čime se potvrđuje 'samonadilazeća kvaliteta' (self-transcending quality)

naše istraživanje, korisno je napomenuti da je Tillich svoj 'ontološki' pristup teoriji simbola suviše lako povezao $\mathrm{s}$ tomističkim učenjem o analogiji bića u bitku, koje počiva na drukčijim, odnosno 'kozmološkim' metafizičkim zahtjevima. Ovo pionirsko i prilično nategnuto povezivanje izazvalo je nove kritike Tillichova učenja u koje mi ne možemo ulaziti, nego ćemo se ograničiti na ovog isusovca: »Toma ne treba Tillichovo ljubazno opravdanje tomističke analogije pomoću njenog svođenja na simbolizam. Zapravo, Toma pronalazi nekakvo opravdanje za Tillichov simbolizam zbog toga što je to slab putokaz prema solidnoj, neizbježnoj ontološkoj analogiji. Tomistička nam analogija ne daje sveobuhvatno razumijevanje Boga, ali nam u danim ljudskim ograničenostima daje odgovarajuću shvatljivost Boga. Analogija ne definira Boga, zato što, kako sv. Toma kaže, on ne može biti definiran (...) Ali ovaj nedostatak ne znači da on ne može biti shvaćen ni na koji način. Razumijevanje je nesavršeno i proporcionalno. Mi znamo da Bog postoji, ali ne možemo znati jasno i točno što je on. Tillichov očigledni naturalizam može biti shvaćen u svjetlu tomističke analogije, a u tom smislu njegov rad može biti silno koristan za katoličke teologe. Tome se može prigovoriti da Tillich izričito odbija tomističku analogiju. To je točno, ali je također točno da može dosljedno uzeti sve od učenja sv. Tome, a zacijelo je i uzeo mnogo toga.« G. WEIGEL, Tillich's Theological Significance, u: T. A. O’MEARA, C. D. WEISSER (ur.), Paul Tillich in Catholic Thought, Dubuque, 1964., 21.-22.

${ }^{20}$ Vidi P. TILLICH, The Meaning and Justification of Religious Symbols, 417.-418. Upravo je ovdje riječ o toj 'novoj' interpretaciji (restatement) religijskih simbola koja je, kako je rečeno, ostala bez većeg odjeka jer je samo potvrdila autorove ranije stavove. 
ovog pristupa koji ukazuje izvan svoje konačnosti. Pritom je važno naglasiti da se oba pristupa međusobno potkrepljuju, jer rezultat fenomenološke analize predstavlja središnji predmet ontološke analize i religijskih simbola, kao i to da prva analiza ne predstavlja razmatranje valjanosti, nego običan opis dotičnog predmeta na koji nas simboli upućuju, a kojem autor i u kontekstu njegove ontološke analize daje poznate metaforičke nazive. ${ }^{21}$

\subsection{NARAVNI NIVO}

S obzirom na drugi 'naravni nivo' (immanent level) religijskih simbola, koji je 'podržan' od temeljnog i 'podupirućeg' transcendentnog nivoa koji smo upravo razmotrili, ovaj imanentni nivo ukazuje na nešto izvan sebe i 'otvara nivoe stvarnosti' (opening up levels of reality), što u ovom kontekstu predstavlja nadnaravno područje zbog kojega su simboli i uspostavljeni. Već smo napomenuli da za razliku od prethodnih 'stvarnih' ili 'ukazujućih simbola' (pointing symbols), autor ove druge naziva 'samonadilazećim simbolima' (self-transcending symobols), a taj zahtjev za nadilaženjem simbola dolazi do izražaja i kada govorimo o Božjim djelima, primjerice, da je Bog 'stvorio svijet' ili 'poslao svog Sina'. Pritom se koristimo pojmovima prostornovremenske uzročnosti iz našeg svakodnevnog iskustva, što je također svojevrsna 'građa' za simbolički govor o Bogu. Međutim, njen se smisao i u ovom kontekstu mora negirati s obzirom na njeno doslovno značenje, ali i potvrditi s obzirom na njeno samonadilazeće značenje, jer je Bog izvan 'našeg' poimanja vremena i prostora. Svako zanemarivanje ove činjenice vodi besmislenim konstatacijama koje imaju za posljedicu pogubne i nerješive sukobe sa znanstvenom interpretacijom stvarnosti, a što opet vodi razaranju i napuštanju same religije kao 'legla besmislenosti', koje izjavama poput Božjeg 'predodređivanja' ili 'svemogućih' činova samo pogoduju zastarjelim zabludama i praznovjerju. Najstarija su od svih božanska očitovanja i pojavljivanja u konačnoj stvarnosti svijeta, odnosno božanska 'utjelovljenja' (incarnations) u svetim mjestima, različitim predmetima, osobama ili događajima, i to ovdje i sada, što je oduvijek bila karakteristika svih poganskih religija, a ne isključiva baština kršćanstva. Kod prvih, s obzirom na utjelovljenje, nema nikakve razlike između nadnaravnog i naravnog nivoa različitih simbola utjelovljenja, jer božanska mistička snaga koja se može zahvatiti samo putem obreda prožima, ali istovremeno i nadilazi svekoliku stvarnost, kao što je to bio slučaj sa silnim mnoštvom bogova

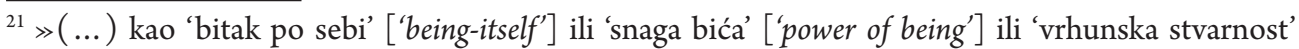
['ultimate reality'] ili 'vrhunska briga' ['ultimate concern'] (u smislu onoga o čemu se netko vrhunski brine). Takvi nazivi nisu nazivi bića, nego kvalitete bića. Ako religijski simboli izražavaju tu kvalitetu božanskim nazivima, klasična je teologija uvijek tvrdila da predmet [referent] tih naziva beskonačno nadilazi njihovo nesimboličko značenje.« P. TILLICH, The Meaning and Justification of Religious Symbols, 418. 
velikih mitologija koje su se razvile u staroj Grčkoj, semitskim narodima i Indiji. Stoga autor naglašava da je 'sakramentalna prisutnost' (sacramental presence) Svetog trajni temelj svih religijskih iskustava, a bitno različita nadnaravnost na koju je uzdignuto ono božansko predstavlja kasniji razvoj, koji je bio i ostao rezultat borbe viših religija, odnosno kršćanstva protiv demonskog iskrivljavanja sakramentalnih religija. Tome ide u prilog i njegovo viđenje sakramentalne odnosno otajstvene 'prisutnosti' koja:

$\gg($... ) nije ništa drugo nego nekakva stvarnost koja postaje nosilac Svetog na poseban način i u posebnim okolnostima. U tom smislu Gospodnja je večera [the Lord's Supper] ili, bolje rečeno, građa Gospodnje večere simbolička. Sada ćete pitati: 'samo simbolička?' To zvuči kao da u njoj [građi] ima nešto više od simboličkog, to jest kada bi se ona shvaćala 'doslovno' ['literal']. Ali doslovno nije više, nego manje od simboličkog. Ako govorimo o onim dimenzijama stvarnosti kojima ne možemo prići ni na jedan drugi način osim simboličkog, tada simboli nisu korišteni u izražavanju onog 'samo', nego u označavanju onog nužnog, s obzirom na koje ih moramo 'primijeniti'. Ponekad, samo zbog brkanja znakova i simbola, izraz 'samo simbol' znači 'samo znak'. Tada je pitanje opravdano. 'Samo znak?' 'Ne.' Sakrament nije samo znak. (... ) U pravilnom poimanju simbola sakramentalna građa predstavlja simbole. Ali ako je simbol korišten 'samo' kao simbol (na primjer, samo kao znak), onda je naravno sakramentalna građa više od toga. $\ll^{22}$

\section{Istinitost religijskih simbola}

Već smo naglasili da je Bezuvjetno 'kvaliteta' koja se ne može poistovjetiti s nekim konkretnim predmetom ili bićem u svijetu, pa čak ni s Bogom, jer 'Bog je bezuvjetan', što ga čini Bogom, ali 'bezuvjetno nije Bog', nego je to 'izraz' koji podrazumijeva bezuvjetan zahtjev kod onih koji su 'svjesni nečeg bezuvjetnog', a kako se to ne može objasniti načelima razumskog zaključivanja, onda i naš odnos prema tome mora biti izražen simbolički. ${ }^{23} \mathrm{Mi}$, naime, ne možemo komunicirati s Bogom ako je

\footnotetext{
${ }^{22}$ P. TILLICH, The Nature of Religious Language, 64.-65. Autor u ovom kontekstu podsjeća na poznatu raspravu između Luthera i Zwinglija u Marburgu 1525., u kojoj je pripadnik njegove vjeroispovijesti želio nastaviti izvorni simbolički karakter sakramentalne građe, dok je Zwingli smatrao da je ona u obliku kruha i vina 'samo simbolička', a što zapravo znači da su to 'samo znakovi' koji ukazuju na priču koja se dogodila u prošlosti. Prvi je u tom smislu zastupao tzv. konsupstancijaciju, a drugi komemoraciju, u što mi ovdje ne možemo ulaziti, nego samo uputiti na K. RAHNER, H. VORGRIMLER, Konsupstancijacija, u: Teološki rječnik, Đakovo, 1992., 250.-251.

23 »Istinitost simbola ovisi o njegovoj nutarnjoj nužnosti za simboličko stvaranje svijesti [symbolcreating consciousness]. Sumnja u njegovu istinitost pokazuje promjenu načina mišljenja, odnosno novi stav prema bezuvjetno nadnaravnom [the unconditioned transcendent]. Jedini kriterij za koji se
} 
on izražen samo apstraktnim pojmom, na primjer, 'Bitak po sebi' koji su skolastici poput Tome Akvinskog nazivali esse ipsum ili esse qua esse, ali se ne možemo obraćati ni njegovim pripadajućim metaforičkim izrazima koje smo već navodili u različitim kontekstima. Zbog toga je nužno da se Bogu obraćamo kao 'osobi', jer on ne može biti ništa manje nego ono što je 'najuzvišenije' u nama kao ljudskim bićima koja je stvorio na svoju sliku i priliku, a to opet, kako je rečeno, uključuje simboličku građu iz našeg doživljaja sebe i svijeta koji nas okružuje. To je razlog zašto Boga najčešće oslovljavamo kao savršenstvo dobrote i milosrdne ljubavi, obraćajući mu se kao sveprisutnom, sveznajućem, svemogućem i vječnom biću, ali je pritom važno naglasiti da se ti atributi ne mogu primijeniti na Boga u doslovnom smislu (literal sense), jer bi to vodilo beskonačnom obilju besmislenosti i razaranju religije, što se, nažalost, vrlo često i događa. A kako bi se izbjegle pogubne konotacije takvog jednoznačnog govora o Bogu, autor zagovara korištenje simboličke građe koja se via eminentiae uzdiže do Boga i tako nadilazi vlastite karakteristike, koje su zajedničke svim kontingentnim bićima pa i najvišima među njima. ${ }^{24}$

Premda naše znanje o Bogu koje proizlazi iz konkretnih očitovanja Bezuvjetnog može predstavljati samo relativnu, pripremnu i iskrivljenu istinu, ono je ipak istinito, ali u specifično egzistencijalnom, a ne teorijskom smislu. Stoga da bismo takvu 'egzistencijalnu istinu' i doživjeli, moramo joj se potpuno predati. Naime, simboli nam ne pružaju objektivno znanje, nego samo 'istinitu svijest' o neshvatljivom temelju koji nikada ne može postati tek jedan predmet pokraj svih drugih, nego putem svijesti o Bezuvjetnom prevladavamo 'rascjep' (cleavage) između subjekta i objekta. To je u skladu s uvjerenjem klasične teologije da je Bog 'izvan' ('beyond') egzistencijalnog rascjepa između esencije (essence) i egzistencije (exsistence) i kao takav izvan svih postojećih bića, kao i onih koja će to tek postati, pri čemu i pojam 'izvan' predstavlja još jedan oblik simboličkog izražavanja. A kako bi izbjegao optužbe za 'pansimbolizam' koji lako vodi u čovjekove naturalističke prikaze o 'Bogu', Tillich pored najapstraktnije i jedine nesimboličke tvrdnje o Bogu kao 'Bitku po sebi', uvodi i jednu 'apologetsku' i prilično kontroverznu i paradoksalnu frazu 'Bog

uopće može reći da je mjerodavan jest ovaj: da je Bezuvjetno [the Unconditioned] jasno zahvaćeno u njegovoj bezuvjetnosti. Simbol koji ne ispunjava ovaj zahtjev i uzdiže uvjetovani predmet do dostojanstva Bezuvjetnog, demonski je čak i ako nije neistinit.«P. TILLICH, The Religious Symbol / Symbol and Knowledge (1940-1941), 265.

${ }^{24}$ Tomin trostruki put kojim dolazimo do spoznaje Boga (triplex via cognoscendi Deum) ima i ovdje svoju primjenu: potvrdni put kojim se Bogu pripisuju savršenstva u stvorenim stvarima (via affirmativa), niječni put kojim se od Boga isključuju nesavršenosti stvorenih stvari (via negativa), i put vrhunskog odlikovanja kojim se vrednote stvorenog svijeta uzdižu do beskonačnosti te se kao takve pripisuju Bogu (via eminentiae). 
iznad Boga' teizma i religije, koja se u ovom kontekstu može definirati kao 'ljudski odgovor na očitovanje transcendentnog i bezuvjetnog značenja':

$\gg($... ) izraz 'Bog iznad Boga' ['God above God'] nije zamišljen kao naznaka da bi se netko trebao odreći tradicionalnih simbola i uzdići se izravno do nadnaravnog Boga, nego je izraz zamišljen kao kritička zaštita protiv pokušaja da se simboli tumače doslovno [literally] i tako brkaju predodžbe o Bogu s onim na što oni ukazuju, naime na ono vrhunsko u biću i značenju. ( ... ) Bog iznad Boga i Bog kojem se možemo moliti jest isti Bog. To govorim onima koji se osjećaju ugroženima od izraza 'Bog iznad Boga'. Ostalima, koji su u radikalnoj sumnji i onima koji žive u dubokoj uznemirenosti oko kršćanske slike o Bogu, rekao bih: 'Nadiđite simbole jer oni sami žele da tako činite. To je ono što oni zahtijevaju. Svojom sumnjom i svojim nemirom svjedočite ono o čemu je izraz 'Bog iznad Boga' paradoksalno izražavanje: Vrhunsko [the Ultimate] i Sveto po sebi [the Holy-itself]': $\ll 5$

Budući da simboli ukazuju na 'bezuvjetno nadnaravno' (the unconditioned transcendent), odnosno Vrhunsko i Sveto koje ih beskonačno nadilazi, otvaraju dublje nivoe stvarnosti i više nivoe svijesti, ali i zbog svog 'čudesno-fantastičnog karaktera', oni ne mogu biti predmetom bilo kakve kritike nesimboličkog jezika pozitivnih znanosti koje se oslanjaju na empirijsko ili povijesno istraživanje. Priče o bogovima i različiti mitovi mogu biti kritizirani samo s gledišta drugih mitova, koji su kao skup određenih simbola nastali u drukčijim okolnostima iz kojih proizlaze i različiti odnosi čovjeka prema njegovom božanstvu, pa su tako i simboli istiniti ako na odgovarajući način izražavaju takav odnos. ${ }^{26}$ Klasične primjere promjene tog odnosa, a time i uloge simbola u njemu, Tillich razmatra kroz dva primjera koja su povezana s Isusovom majkom Marijom ili, kako ju se dugo častilo, 'Svetom Djevicom' (Holy Virgin), a drugi je primjer priča o 'djevičanskom rođenju Isusa' (virginal birth of Jesus). U prvom primjeru riječ je o simbolu koji je u protestantizmu 'umro' s pojavom posebnog, izravnog i neposrednog odnosa prema Bogu, jer je taj novi odnos uz negaciju asketskog elementa i glorifikacije djevičanstva učinio nemogućom bilo kakvu 'posredničku snagu' tog simbola. Premda protestantski znanstvenici nisu vidjeli nikakav empirijski razlog za takva vjerovanja s obzirom na Mariju, njihova

${ }^{25}$ P. TILLICH, The God above God, u: P. TILLICH: Theological Writings, Main Works = Hauptwerke, 6, Gert Hummel (ur.), Berlin - New York, 1992., 419.-421.

26 》Simbolički jezik religije izraz je čovjekova stvarnog odnosa prema onome što ga vrhunski brine [concerns him ultimately]. Ako se narav ovog odnosa mijenja, simbol se također mijenja, a ova su dva procesa često međusobno ovisna. Promijenjeni simboli izražavaju i učinak promijenjenog odnosa prema svetom [the holy].« P. TILLICH, The Word of God, u: P. TILLICH: Writings in the Philosophy of Religion, Main Works = Hauptwerke, 4, John P. Clayton (ur.), Berlin - New York, 1987., 412 . 
je uloga u nestajanju simbola Marijina djevičanstva zanemariva, a svega toga, po autorovu mišljenju, svjesna je i Rimska crkva, koja zbog goleme snage tog simbola polako 'približava' Mariju i samom Trojstvu. ${ }^{27} \mathrm{~A}$ s obzirom na drugi primjer, ${ }^{28}$ autor na temelju povijesnih istraživanja smatra da je tu očigledno riječ o legendarnoj priči koja je bila nepoznata sv. Pavlu i sv. Ivanu evanđelistu, ali je kasnije nastala u pokušaju da se lakše shvati kako je Isus iz Nazareta u potpunom posjedu božanskog Duha. Ali i ovdje fantastičnost priče nije razlog nestajanja ovog simbola, čak i kod prilično konzervativnih grupa unutar protestantskih crkava, nego je riječ o teološkom i gotovo 'heretičkom razlogu' koji se sastoji od zanemarivanja klasičnog kršćanskog učenja da 'potpuno Isusovo čovještvo' mora uključivati i njegovo 'potpuno božanstvo.29 Međutim, ako ljudska osoba nema i ljudskog oca u naravnom smislu, onda ne možemo govoriti ni o 'potpuno ljudskoj naravi', kako to s obzirom na Isusovu dvojnu narav nalaže Kalcedonski sabor. Stoga autor zaključuje da i ova priča treba biti kritizirana na temelju njenog simboličkog izražavanja, a ne na temelju njene povijesne istinitosti:

$\gg$ Ovo je negativna tvrdnja o istinitosti religijskih simbola. Njihova se istina sastoji od njihove podudarnosti s religijskom situacijom u kojoj su nastali, a njihova nepodudarnost $\mathrm{s}$ drugom situacijom njihova je neistina. U posljednjoj rečenici obuhvaćene su obje ove tvrdnje o simbolima: pozitivna i negativna. ${ }^{30}$

${ }^{27}$ Papa Pio IX. staro je vjerovanje da je Marija začeta bez istočnog grijeha proglasio dogmom 1854., odnosno da je s 'obzirom na Kristove zasluge sačuvana od svake ljage istočnog grijeha', ali Tillich smatra da je Marijino 'približavanje' Trojstvu posebno došlo do izražaja nakon što je 1950. Pio XII. proglasio dogmu o Uznesenju Marijinu, kao svojevrsnom tjelesnom preobraženju bezgrešno začete Bogorodice. Ako bi se po zagovoru nekih katoličkih teologa takvo približavanje ostvarilo, Tillich u tome vidi Mariju kao 'suspasiteljicu' (co-Saviour) zajedno s Isusom, ali i bez obzira na to smatra da se Mariju pretjerano uzdiglo do samog božanstva. I premda je vjerovao u mogućnost reinterpretacije velikih simbola prošlosti tako da se nekima od njih obnovi značenje, ipak je rekao da bi: »( ... ) pod kaznom otpuštanja zabranio bilo kojem svećeniku uporabu izraza 'prvotni grijeh' ['original sin'] za sljedećih trideset godina, sve dok ovaj izraz ponovno ne zadobije nekakvo značenje. Ali kako je neizvjesno da će on ikada vratiti bilo kakvo značenje, vjerojatno ga treba potpuno odbaciti.«P. TILLICH, The Restoration of Religious Symbols, 89.

${ }^{28}$ Vidi R. E. BROWN, Isusovo djevičansko začeće i tjelesno uskrsnuće, Zagreb, 2011., 17.-96.

${ }^{29}$ Tillich misli na četvrti ekumenski sabor koji je za vrijeme pontifikata pape Leona I. održan u Kalcedonu 451., na kojem je formulirana kristološka dogma: »( ... ) Isus Krist, Božji Logos koji je postao čovjekom, jedna je osoba u dvjema naravima koje su u toj jednoj osobi nepomiješane, nepromijenjene, nerastavljene i neodvojene (DS 301 sl., NR 178), protiv nestorijanstva (dvije osobe u Isusu Kristu; usp. Efez) i protiv Eutihove nauke (dvije su naravi u Isusu Kristu pomiješane u jednoj jedinoj naravi: strogi monofizitizam).« K. RAHNER, H. VORGRIMLER, Kalcedon, u: Teološki rječnik, Đakovo, 1992., 232.-233.

${ }^{30}$ P. TILLICH, The Nature of Religious Language, 66. 
Tillich također naglašava da bilo kakva kritika simbola na temelju njihove proturječnosti s prirodnim zakonima ili povijesnim činjenicama vodi u krajnje besmisleno brkanje simboličkog i znanstvenog jezika, a kako oba jezika izražavaju različitu stvarnost, doći će i do kobnog brkanja različitih dimenzija stvarnosti. ${ }^{31} \mathrm{U}$ tom smislu potpuno je besmislena i rasprava o 'postojanju' ili 'nepostojanju' Boga, koja od samog početka zapravo predstavlja negaciju ideje o Bogu koja vodi u ateizam, jer ako pod pojmom 'postojanje' (existence) podrazumijevamo nešto što se može naći u svekolikoj stvarnosti, onda nijedno božansko biće ne postoji. 'Postojanje Boga' nemoguća je kombinacija riječi kojom svodimo Božju transcendentnu narav na nivo kontingentnih bića; stoga je besmislen svaki znanstveni pokušaj nijekanja religije zbog nemogućnosti dokazivanja Božje egzistencije, kao što je besmislena i tvrdnja mnogih teologa kako 'postoji najviše biće zvano Bog'. Poimanje Boga kao 'bića', pa čak i kao najvišeg ili najsavršenijeg među bićima, predstavlja proturječje u pojmovima i lišava Boga njegovog božanstva, odnosno njegovog bezuvjetnog karaktera, pa bi takav bog postao relativan u odnosu na svijet i tako samo njegov dio i obično uvjetovano biće poput svih drugih. To bi bio 'Bog ispod Boga' (God beneath God), odnosno Bog deizma, ili 'Bog panteizma' u kojem samodostatni svemir ima svoj bitak u samom sebi, ali kako smo pokazali: 'istinsko Bezuvjetno leži izvan takvog Boga i svijeta., ${ }^{32}$

Međutim, Tillich napominje da raspravu o Božjoj egzistenciji moramo razlikovati od problema istinitosti ili neistinitosti religijskih tvrdnji i simbola, jer ni u jednom području života pitanje o istini nema tako presudnu ulogu kao što je to slučaj s religijom. Zbog toga nedostatak istine u religijskim simbolima nije samo obična pogreška, nego je riječ o demonskom iskrivljavanju istine ili idolopoklonstvu koje ima pogubne i dalekosežne posljedice. Ovdje se pitanje o istini odnosi na Boga koji je doista Bog, a ne na konačno biće koje se uzdiže do božanske vrijednosti. To je pitanje koje se odnosi na istinitu ili krivu interpretaciju značenja Bitka po sebi ili naše vrhunske brige. Nacionalističko idolopoklonstvo nije lažno zato što ne postoje nacionalni bogovi u smislu u kojem postoje stabla, misli ili zvijezde, nego

${ }^{31} \gg$ Istina religijskih simbola nema ništa s istinom empirijskih tvrdnji koje su u to uključene, bilo da su one fizikalne, psihološke ili povijesne. Religijski simbol posjeduje svojevrsnu istinu ako adekvatno izražava međusobni odnos [correlation] objave i neke osobe koja u nju vjeruje. Religijski 'je' simbol istinit ako adekvatno izražava povezanost neke osobe s konačnom objavom. Religijski simbol može umrijeti samo ako povezanost koju se na takav [simbolički] način nastoji adekvatno izraziti također umire. To se događa uvijek kada se promijeni situacija na koju se objava odnosi, a prijašnji simboli postanu zastarjeli. Povijest religije sve do našeg vremena puna je mrtvih simbola, koji nisu bili ubijeni znanstvenom kritikom zbog pretpostavljenog praznovjerja, nego religijskom kritikom religije. $\ll$ P. TILLICH, God as Being and the Knowledge of God, 240.

${ }^{32}$ Vidi P. TILLICH, The Conquest of the Concept of Religion in the Philosophy of Religion, u: J. L. ADAMS (ur.), What is Religion, New York, 1969., 125. 
se takva neistina očituje tako što nacija postane nečija vrhunska briga, a time i idol, odnosno demonski simbol. Stoga se pitanje o tzv. 'postojanju Boga' mora zamijeniti pitanjem: koji od bezbrojnih simbola najviše odgovara sadržaju i značenju vjere, odnosno koji simboli 'vrhunskog' (the ultimate) izražavaju to vrhunsko bez idolopokloničkih elemenata? Tillich smatra da je to simbol raspetog Krista na križu (cross of the Christ), koji kao konačni kriterij religijskih simbola relativizira svu simboličku građu, pa tako i vlastitu, predstavljajući tako glavnog čuvara protiv njihova demoniziranja, da ne postanu sami sebi svrhom i predmetom idolopokloničkog obožavanja. ${ }^{33}$ Po tom simbolu kršćanstvo polaže pravo na istinu koja je nadmoćna bilo kojoj drugoj istini u njenom simbolizmu, ali je pritom važno naglasiti da taj simbol nadilazi i samu kršćansku religiju, jer:

$\gg$ On, koji utjelovljuje puninu božanske prisutnosti žrtvuje sam sebe kako ne bi postao idol, još jedan bog pored Boga, bog kojim su ga učenici htjeli učiniti. Zbog toga je presudna priča ona u kojoj on prihvaća od Petra ponuđeni naziv 'Krist'. On to prihvaća pod uvjetom da ode u Jeruzalem podnijeti muku i umrijeti, a to znači zanijekati idolopokloničku sklonost, pa i s obzirom na njega samog. To je istovremeno kriterij svih drugih simbola, odnosno mjerilo kojem se treba podvrgnuti svaka kršćanska crkva. $\ll^{34}$

\section{Zaključak}

Budući da je smatrao kako su 'doslovne' i 'nadnaravne' interpretacije vjerskih učenja pogodovale izoliranju teološke refleksije od interesa suvremenog društva, čime su

33 »( ... ) križ simbolizira osvajanje demonske kušnje kao snage koju susrećemo u svakoj religiji, u svakom religijskom vođi i u svakom svećeniku. A ja bih dodao da Rimska crkva nije pravilno shvatila značenje tog prizora [raspeti Krist na križu], a uslijed toga ni značenje križa. (...) Predstavljana papom, crkva od sebe čini nešto apsolutno što ne treba umrijeti, nego nastaviti ekskluzivnu strukturu i valjanost. $\ll$ P. TILLICH, The Kairos and the Cross, u: B. D. MACKENZIE (ur.), Ultimate Concern: Tillich in Dialogue, New York - London, 1970., 136.

${ }^{34}$ P. TILLICH, The Nature of Religious Language, 67. U tom smislu autorova teorija religijskih simbola pretpostavlja da vrhunska briga (ultimate concern), odnosno temelj značenja i bića (ground of meaning and being) 'ima' vrhunsku istinu (the ultimate truth), koja je uvjet bilo kakve relativne i kao takve samo pripremne istine. Pritom nam simboli donose religijsku sigurnost koja na ovaj način počiva na svom stvarnom i apsolutnom temelju, daleko od beskonačne nesigurnosti prosudbi o Božjem postojanju ili nepostojanju koje imaju samo vjerojatnu vrijednost, jer: »Bog je kao vrhunski u čovjekovoj vrhunskoj brizi sigurniji od bilo koje druge izvjesnosti, čak i od izvjesnosti samog čovjeka. Bog koji je simboliziran u božanskom liku zahtijeva odvažnost vjere, hrabrost i rizik.« P. TILLICH, Symbols of Faith, 54. U svakom slučaju: »( ... ) simboli božanskog mogu se pojaviti samo u egzistencijalnoj situaciji vrhunske brige, a izvan su te situacije besmisleni.« P. TILLICH, An Afterword: Appreciation and Reply, u: T. A. O'MEARA, C. D. WEISSER (ur.), Paul Tillich in Catholic Thought, Dubuque, 1964., 306. 
mnogi tradicionalno ključni simboli kršćanstva sve više gubili svoju 'snagu' tako što su za većinu ljudi imali sve manje 'smisla', Tillich je zagovarao filozofiju religije koja bi pomogla osnaživanju značenja simbola i rasvjetljavanju simboličke prirode glavnih vjerskih učenja, tako da ih razumiju i svjetovni ljudi u koje je ubrajao i vjernike. Stoga je naglašavao reprezentativnu funkciju simbola s kojom oni poput znakova 'ukazuju' na stvarnost koja je 'izvan' njih i 'različita' od njih, ali za razliku od znakova simboli participiraju u toj stvarnosti i tako 'otvaraju dimenzije stvarnosti' koje bi nam inače ostale skrivene i nedostupne. Posebnost religijskih simbola u tome je što ukazuju na ono što je 'bezuvjetno, beskonačno i vrhunsko' u čovjekovom duhovnom životu, a to je za Tillicha 'Bitak po sebi' kojeg opisuje kao 'vrhunsku' ili 'svetu' stvarnost, koja bi kao takva trebala biti i naša 'vrhunska briga'. Dakle, pomoću različitih 'simbola Svetog', odnosno svekolike simboličke građe, otkrivamo i nešto od 'Svetog po sebi', pri čemu i sami 'doživljavamo' svetost koja se nalazi u temelju stvarnosti i koju ne mogu izraziti nikakvi filozofsko-teološki ili znanstveni pojmovi. Pritom je posebno važno naglasiti da se simboli ne mogu i ne smiju poistovjećivati s onim što simboliziraju, kako ne bi došlo do njihova demoniziranja, odnosno do tog da se apsolutiziraju te tako postanu sami sebi svrhom i predmetom idolopokloničkog obožavanja, nego da kao 'sredstvo' ukazivanja na Sveto moraju sadržavati i svoju vlastitu negaciju, a što je zapravo afirmacija one stvarnosti koja nam u svojoj biti ostaje do kraja nespoznatljiva. U tom smislu simbol raspetog Krista na križu najviše odgovara sadržaju i značenju vjere, a kao konačni kriterij svih religijskih simbola predstavlja glavnog čuvara protiv njihova demoniziranja. 


\title{
TILLICH'S THEORY OF RELIGIOUS SYMBOLS
}

\author{
Dubravko ARBANAS*
}

Summary: Although Paul Tillich, as he himself confessed, directed his whole theological work towards an interpretation of religious symbols so that all people could understand them, he caused a great deal of polemics with his theory of symbols, or religious language. Therefore, our intention is to show its seminal determinants. The focus of the research is on several of his key essays and the study methodology also includes an analysis of relevant ideas of his most prominent critics. Through critical analysis, the author concluded that Tillich primarily wanted to overcome the devastating consequences of "literal' and 'supernatural' interpretation of religious teachings, which is why he advocated a philosophy of religion that would help strengthen the significance of the symbols and shed light on the symbolic nature of the main religious teachings. In doing so, he especially emphasized that the symbols must never be identified with what they symbolize, so they wouldn't be demonized or turned into the absolutes, and in that way become their own purpose and an object of idolatry. Instead, as an 'instrument' of pointing to the Holy, the symbols must also include their own negation, which is in fact the affirmation of the reality that in its essence remains unknowable to us in its entirety. In this sense, the symbol of the Christ crucified on the cross meets the content and meaning of faith to the greatest extent, and as the final criterion of all religious symbols, it represents the main guardian against their demonization.

Keywords: sign, symbol, participation, religious language, faith, the Unconditional, the Ultimate, the Holy, God, Christ, truth.

* Dubravko Arbanas, Ph. D., Trg Slobode 5, 31000 Osijek, Croatia, adubravko@gmail.com 